The Free Internet Journal for Organic Chemistry
Paper

Arkivoc 2019, part v, 0-0

to be inserted by editorial office

\title{
Convenient approach to novel tetracyclic-fused pyranoquinolinone compounds from 6-n-butyl-3-amino-4-hydroxypyrano[3,2-c]quinolinone
}

\author{
Hany M. Hassanin \\ Department of Chemistry, Faculty of Education, Ain Shams University Roxy 11711 Cairo, Egypt \\ Email: hanyhassnin@gmail.com
}

Received 03-19-2019

Accepted 04-25-2019

Published on line $05-04-2019$

\section{Abstract}

6-n-Butyl-3-aminopyrano[3,2-c]quinoline-2,5-dione has been synthesized and utilized to obtain various new heteroannulated pyranoquinolinones, containing pyrazine, oxazine, [1,2,4]triazine and oxadiazine in good yields. The newly synthesized compounds were characterized by spectral data and elemental analysis.

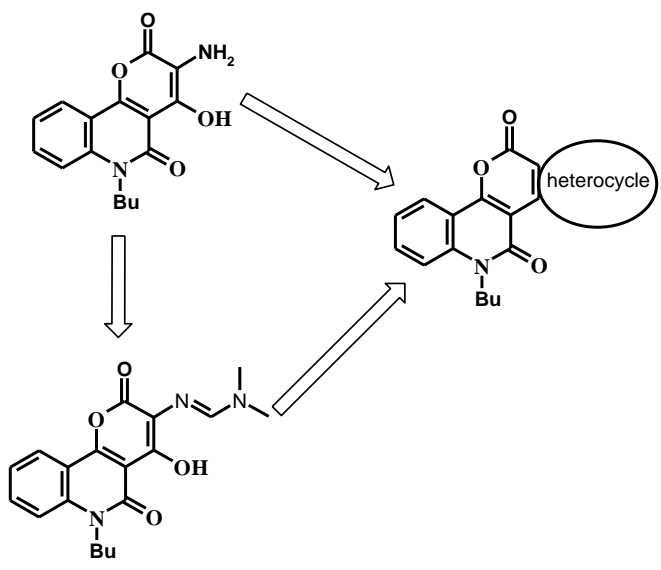

Keywords: Quinolinone, pyranoquinolinone, pyrazine, triazine, oxazine, oxadiazine 


\section{Introduction}

Nitrogen containing heterocyclic compounds represent a notable type of anticancer drug applicants, which strongly activate cell apoptosis. ${ }^{1}$ Many quinoline containing compounds have been reported as potential antitumor agents. ${ }^{2,3}$ Quinoline skeleton perform an important aspect in anticancer drug improvement, as their derivatives show great results through different operations such as growth inhibitors by cell cycle arrest, apoptosis, inhibition of angiogenesis, disruption of cell migration, and modulation of nuclear receptor responsiveness. ${ }^{4}$ Alkaloids with pyrano[3,2-c] quinolone feature exhibit very wide range of biological activities. ${ }^{5}$ Additionally, 6- $n$-butylpyranoquinolone derivatives reveal highly forceful TOP2B inhibitors ${ }^{6}$ and disclose the highest cancer cell growth-inhibitory activity against different tumor cell lines.7,8 Addition a further heterocyclic ring to pyranoquinolinone scaffolds represent as a valuable performance for designing novel drugs by enhancing their biological effects and permit them to serve as antibacterial, ${ }^{9}$ anticoagulant, ${ }^{10}$ antitumor, ${ }^{11}$ and microtubule-targeting agents. ${ }^{5}$ Pyrazines are vital for our life due to their DNA strandbreakage activity and apoptosis efficiency. ${ }^{12}$ Synthetic pyrazine derivatives are useful as antiviral, anticancer, antibacterial, fungicidal, and herbicidal drugs. ${ }^{13}$ Otherwise, oxazine derivatives exhibit significant anticoagulant, ${ }^{14}$ antibacterial and antifungal activity. ${ }^{15}$ Additionally, compounds containing oxadiazine ring exhibit pronounced antibacterial, antifungal, ${ }^{16,17}$ antitumor ${ }^{18}$ and insecticidal activities. ${ }^{19}$ Likewise, the $1,2,4$ triazine ring is a prominent structural core found in diverse biologically active systems and demonstrate an influential considerable group of antitumours. ${ }^{20-24}$ Heartened by exclusive facial characteristics of pyrazine, oxazine, triazine and oxadiazine, beyond their recorded promising bioactivity, it would be an attractive suggestion to merge the previous impressive heterocycles with 6 - $n$-butylpyranoquinolinone moiety at face $c$ in an individual molecular scaffolding. We pursue to devise innovative biological activity for the newly synthesized compounds.

\section{Results and Discussion}

The 3-aminopyranoquinolinone 1 was prepared by the method reported by Hassanin et al. ${ }^{25} \mathrm{~N}$-Alkylated derivatives of amines are important synthetic intermediates in organic synthesis. Thus, reaction of compound 1 with bromoacetonitrile, in molar ratio (1:1) in boiling acetonitrile containing sodium hydride as a basic catalyst under dry nitrogen gas atmosphere was carried out (Scheme 1). The bearable products of this alkylation are either $\mathrm{N}$-alkylated $\mathbf{2}$ or $\mathrm{O}$-alkylated 3. In other previous studies, higher regioselectivity favoring $\mathrm{N}$-alkylation was observed and the $\mathrm{N}$-alkylated products were obtained in moderate to good isolated yields with only very small traces of O-alkylated products were detected. ${ }^{26,27}$ 


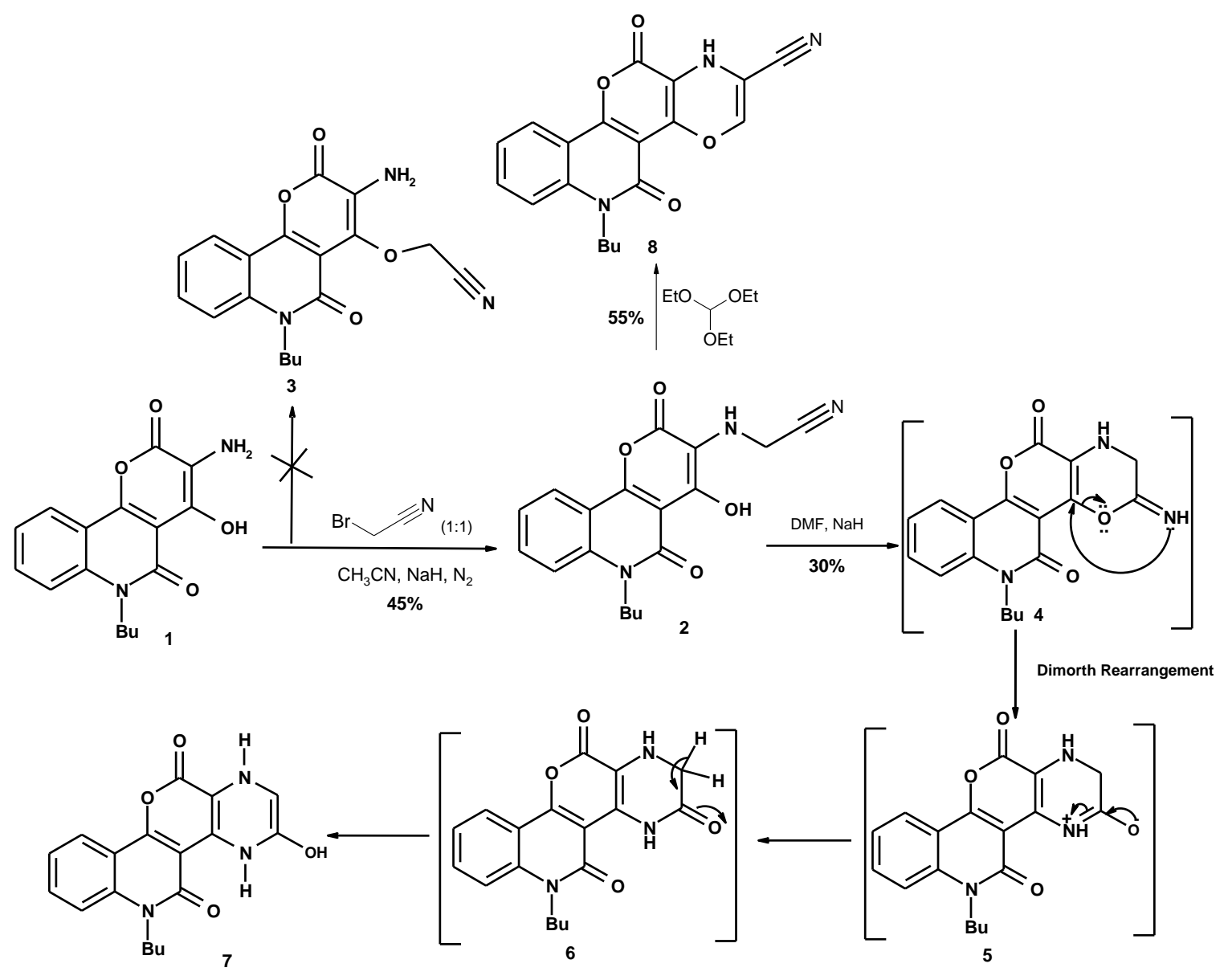

Scheme 1.

Our product of alkylation gave a strong positive result with iron III chloride solution and it dissolved easily in diluted sodium hydroxide solution. These two observations indicate the presence of phenolic $\mathrm{O}-\mathrm{H}$. The IR spectrum of the product proved the non-changeable of $\mathrm{OH}$ band and nonappearance of the amino group, in addition to presence of two new stretching vibration bands at 3203 and $2188 \mathrm{~cm}^{-1}$ due to $\mathrm{NH}$ and $\mathrm{C} \equiv \mathrm{N}$ groups, respectively. ${ }^{1} \mathrm{H}$ NMR spectrum showed a new distinguishable singlet signal at 4.29 ppm referred to $\mathrm{CH}_{2}-\mathrm{CN}$ group and the presence of two deuterium-exchangeable protons, at 7.12 and 14.08 ppm, for the $\mathrm{N}-\mathrm{H}$ and $\mathrm{O}-\mathrm{H}$ protons, respectively. In addition, ${ }^{13} \mathrm{C}$ NMR spectrum of the product revealed a new $s p^{3}$ hybridized carbon atom at $31.1 \mathrm{ppm}$ attributed to the active methylene group $\left(\mathrm{NHCH}_{2} \mathrm{CN}\right)$. Building on the above experimental and spectral analyses of the product, we assumed that a similar attitude of the literature was also observed and the $\mathrm{N}$-alkylated compound $\mathbf{2}$ was the predominant regioisomer in moderate yield (45\%). Also, the structure of compound 2 was supported by its mass spectrum which exhibited a molecular ion peak at $\mathrm{m} / \mathrm{z} 339$ ( $\left.\mathrm{M}^{+} ; 89 \%\right)$. Boiling acetonitrile derivative 2 , in DMF containing sodium hydride as a basic catalyst, affected its intramolecular heterocyclization to produce intermediate compound $\mathbf{4}$ which subjected to Dimroth rearrangement under the reaction conditions to give the non-isolable intermediate compound 7 . Therefore, a rearrangement can occur to yield the more stable pyrazinopyranoquinolinone compound $\mathbf{7}$ as described in scheme 1 . The IR spectrum of compound $\mathbf{7}$ verified the absenteeism of the nitrile group. While the ${ }^{1} \mathrm{H}$ NMR spectrum of $\mathbf{7}$ displayed the absence of the active methylene group and the presence of five aromatic signals in the region 7.42-8.05 ppm equivalent to the protons of the aryl functionality of the 
quinolinone and the proton from pyrazine moiety. ${ }^{13} \mathrm{C}-\mathrm{NMR}$ spectrum confirmed the absence of methylene carbon signal at $\delta 31.14 \mathrm{ppm}$ and appearance a new signal at $\delta 122.7 \mathrm{ppm}$ attributed to $s p^{2}$ hybridized carbon atom of pyrazine and other seventeen signals thus compatible with the number of carbon atoms in the molecular formula. The ESI-MS analysis of compound 7 showed an $[\mathrm{M}+\mathrm{H}]^{+}$ion at $\mathrm{m} / \mathrm{z} 340.4$, and an abundant $[\mathrm{M}+\mathrm{Na}]^{+}$ion at $m / z$ 362.2. $\mathrm{A}[2 \mathrm{M}+\mathrm{Na}]^{+}$was also observed at $m / z$ 701.3.

In the continuation of our earlier work on the synthesis of oxazinopyranoquinolinones, ${ }^{28}$ the compound 2 was treated with triethyl orthoformate, under solvent free condition, to afford oxazinopyrano[3,2c]quinolinone $\mathbf{8}$ (Scheme 1). The IR spectrum of compound $\mathbf{8}$ showed the absence of $\mathrm{OH}$ function. The ${ }^{1} \mathrm{H}$ NMR spectrum showed singlet signal at $8.64 \mathrm{ppm}$ distinguishable for oxazine proton and a chemical shift at 9.43 ppm due to $\mathrm{NH}$, which disappeared on deuteration. ${ }^{13} \mathrm{C}-\mathrm{NMR}$ spectrum of compound 8 demonstrated the presence of fourteen aromatic carbons in the region 101-193 ppm due to the annulated tetracyclic system. The ESI-MS spectrum of compound 8 exhibited an $[\mathrm{M}+\mathrm{H}]^{+}$ion at $\mathrm{m} / z 350.3$, and an abundant $[\mathrm{M}+\mathrm{Na}]^{+}$ion at $m / z$ 372.1, in accordance with its structure.

We speculated that adding more amount of alkylating agent, would improve the yield of compound 2 which was formed in low yield (45\%). Amazingly, we obtained a new product with alternative melting point. We supposed that the product may be $\mathrm{N}, \mathrm{O}$-dialkylated product $\mathbf{9}$ or the $\mathrm{N}, \mathrm{N}$-dialkylated product $\mathbf{1 0}$. The product gave a strong positive result with iron III chloride solution and it dissolved easily in diluted sodium hydroxide solution. The IR spectrum of the product proved the absence of the amino group and the appearance of broad band at $3347 \mathrm{~cm}^{-1}$ due to $\mathrm{OH}$ group. The ${ }^{1} \mathrm{H}$ NMR spectrum of the product displayed two characteristic singlet signals at 4.02 and $4.21 \mathrm{ppm}$. Also, ${ }^{13} \mathrm{C}$ NMR spectrum revealed two carbon signals at 41.9, $42.1 \mathrm{ppm}$. Trusting on the above unexpected data, the N,O-dialkylated product 9 was excluded and we expected that further selectively alkylation on the amino group took place to produce the interesting diacetonitrile derivative $\mathbf{1 0}$ which contain two characteristic methylene groups (Scheme 2).

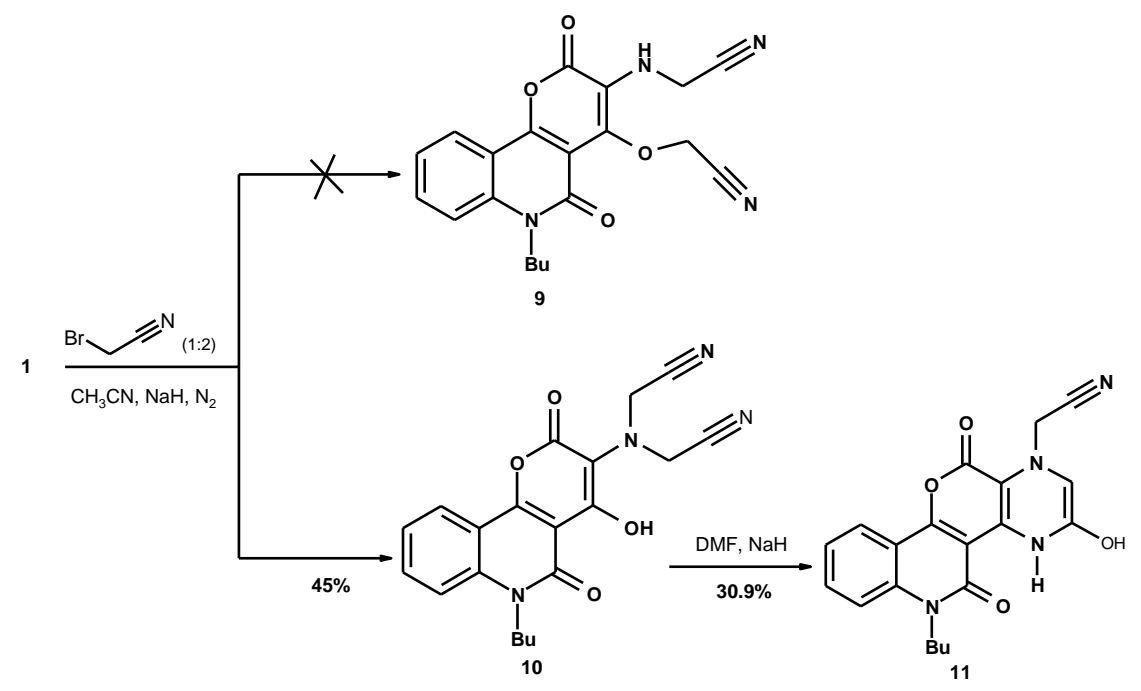

\section{Scheme 2.}

Moreover, the structure of compound $\mathbf{1 0}$ was established by its mass spectrum which revealed the molecular ion peak $\mathrm{M}^{+}$at $\mathrm{m} / \mathrm{z}=378(41 \%)$, and $\mathrm{M}^{+}+1 \mathrm{~m} / \mathrm{z}=379$ (9\%). Pyrazinopyrano[3,2-c]quinolinone 11 was obtained by refluxing of compound 10 in DMF containing sodium hydride as a catalyst, this reaction occurred via intramolecular cyclization of compound 10. The X-ray diffraction study of compound $\mathbf{1 1}$ showed that it has 
polycrystalline nature as many sharp peaks were observed on its XRD chart. ${ }^{1} \mathrm{H}$ NMR spectrum of compound 11 was marked by the existence of five aromatic signals in the region 7.51-8.71 ppm corresponding to the protons of the aryl functionality of the quinolinone and the proton from pyrazine moiety. ${ }^{13} \mathrm{C}-\mathrm{NMR}$ spectrum demonstrated the presence of methylene carbon signal at $\delta 40.9$ and $\delta 117.5 \mathrm{ppm}$ assigned to CN from the acetonitrile group, in addition to a new signal at $\delta 124.9 \mathrm{ppm}$ discernible to $s p^{2}$ carbon atom of pyrazine and other 17 signals which are compatible with the number of carbon atoms in the molecular formula. The ESI-MS spectrum of compound 11 showed a $[\mathrm{M}+\mathrm{H}]^{+}$ion at $\mathrm{m} / z 379.2,[\mathrm{M}+\mathrm{Na}]^{+}$ion at $\mathrm{m} / z 401.2$ and the $[2 \mathrm{M}+\mathrm{Na}]^{+}$ion was also observed at $m / z 779.1$.

We describe here the synthesis of the desired oxazinopyranoquinolinone, triazinopyranoquinolinones and oxadiazinopyranoquinolinone starting from the formamidine compound $\mathbf{1 2}$ which was prepared by treating amine 1 with dimethylformamide dimethylacetal (DMF-DMA). ${ }^{25}$ The compound $\mathbf{1 2}$ was allowed to react with bromoacetonitrile, in boiling tetrahydrofuran containing sodium hydride as a basic catalyst to obtain oxazinopyranoquinolinone 13 in high yield (67\%) as outlined in scheme 3 . The IR spectrum of compound 13 showed the absence of $\mathrm{OH}$ band and the appearance of two new stretching vibration bands at 3365 and 2203 $\mathrm{cm}^{-1}$, due to the $\mathrm{NH}$ and $\mathrm{C} \equiv \mathrm{N}$ groups, respectively. The ${ }^{1} \mathrm{H}$ NMR spectrum showed singlet signal at 8.49 ppm distinguishable for oxazine proton and a deuterium-exchangeable singlet signal at $11.57 \mathrm{ppm}$ assignable to $\mathrm{NH}$ proton. ${ }^{13} \mathrm{C}-\mathrm{NMR}$ spectrum of compound 13 exhibited the nonappearance of two sp3 methyl carbons of formamidine 12 and the presence of fourteen aromatic carbons in the region 101-162 ppm due to the tetracyclic-fused system. Moreover, compound 13 showed a quasimolecular ion peak at $\mathrm{m} / \mathrm{z} 350.1[\mathrm{M}+\mathrm{H}]^{+}$in the positive electrospray ionization-MS corresponding to $\mathrm{C}_{19} \mathrm{H}_{15} \mathrm{~N}_{3} \mathrm{O}_{4}$. (Scheme 3)

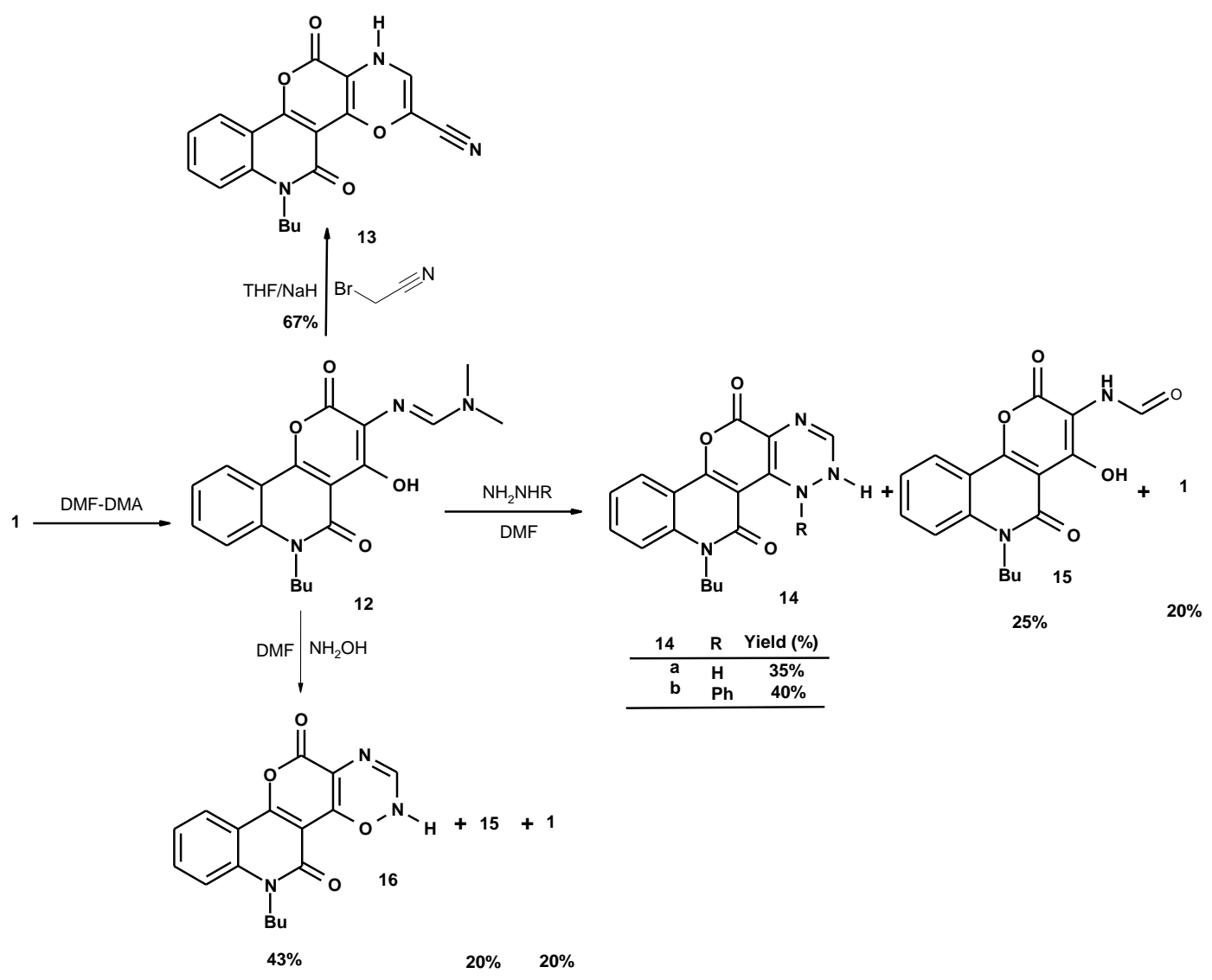

\section{Scheme 3.}


The structure of formamidine $\mathbf{1 2}$ involves variable electron-deficient centers and it is expected to be relatively reactive towards nucleophilic reagents. Therefore, treatment of formamidine 12 with 1,2binucleophiles such as hydrazine hydrate and phenyl hydrazine in DMF was studied to afford triazinopyranoquinolinones $\mathbf{1 4 a}$ and $\mathbf{1 4 b}$ as the main products in low yields (35-40\%) (Scheme 3 ). Proof for the formation of compounds $14 \mathrm{a}$ and $14 \mathrm{~b}$ attained from their ${ }^{1} \mathrm{H}$ NMR spectra where there was a new singlet signal at $8.71 \mathrm{ppm}$ in $14 \mathrm{a}$ and at $8.38 \mathrm{ppm}$ in $14 \mathrm{~b}$ assigned to the proton of triazine moiety. In addition, there are two deuterium-exchangeable signals at $9.10 \mathrm{ppm}$ and $10.11 \mathrm{ppm}$ due to $2 \mathrm{NH}$ protons in compound $14 \mathrm{a}$ and one $(\mathrm{NH})$ at $9.40 \mathrm{ppm}$ in compound 14b, also, nine signals of phenyl and benzo protons which were observed at 6.85 to $8.29 \mathrm{ppm}$ in compound $\mathbf{1 4 b}$. The ${ }^{13} \mathrm{C}$ NMR spectra indicated the presence of seventeen singlet signals in $\mathbf{1 4 a}$ and twenty three singlet signals in 14b which were agreeable with the number of carbon atoms in their molecular formulas. Furthermore, the ESI-MS spectra of compounds 14a and 14b exhibited $[\mathrm{M}+\mathrm{Na}]^{+}$ions ( $\mathrm{m} / \mathrm{z}: 347.1$ and 423.2, respectively) in accordance with their structures. Our attempts to study the reason of the low yield of products $14 a$ and $14 b$ by separating the side products from the mother liquor using chromatography technique were effective. We succeeded to isolate two side products from this reaction. The first one is the amine derivative $\mathbf{1}$ which probably resulted from thermal degradation of the aliphatic chain of compound $\mathbf{1 2}$ in a high boiling point polar solvent. The second side product was isolated in $25 \%$ yield with yellow crystals and distinctive melting point. Interesting observations were achieved from the spectra of this resulting side product. Its IR spectrum revealed a characteristic absorption band at $1679 \mathrm{~cm}^{-1}$ due to new carbonyl group. Also, the ${ }^{1} \mathrm{H}$ NMR spectrum showed the existence of more downfield chemical shift at $10.19 \mathrm{ppm}$, unchangeable with $\mathrm{D}_{2} \mathrm{O}$, which may belong to a formyl function. We think that this phenomenon is happen as a result for hydrolysis of the active formamidine derivative $\mathbf{1 2}$ by water content in the solvent to give formamide derivative 15. The ${ }^{13} \mathrm{C}$ NMR spectrum proved the presence of a formyl group at $177.3 \mathrm{ppm}$. Moreover, the structure of compound 15 was confirmed by its ESI-MS spectrum which disclosed a quasimolecular ion peak at $\mathrm{m} / z 329.3[\mathrm{M}+\mathrm{H}]^{+}$and a sodiated molecular ion peak at $\mathrm{m} / z 351.2[\mathrm{M}+\mathrm{Na}]^{+}$.

The compound $\mathbf{1 2}$ was heated with hydroxylamine hydrochloride in DMF at reflux, to obtain oxadiazinopyranoquinolinone 16. The ${ }^{1} \mathrm{H}$ NMR spectrum of compound $\mathbf{1 6}$ showed a singlet signal at $9.41 \mathrm{ppm}$ assignable for oxadiazine proton and a chemical shift at $12.36 \mathrm{ppm}$ due to $\mathrm{NH}$, which disappeared on deuteration. The ${ }^{13} \mathrm{C}-\mathrm{NMR}$ spectrum of compound 16 revealed the presence of four aliphatic carbon atoms due to the butyl group and thirteen $s p^{2}$ hybridized carbon atoms belonging to the aromatic carbon atoms of oxadiazinopyranoquinolinone system. ESI-MS spectrum of compound $\mathbf{1 6}$ showed a quasimolecular ion peak at $\mathrm{m} / \mathrm{z} 326.3[\mathrm{M}+\mathrm{H}]^{+}$and a sodiated molecular ion peak at $\mathrm{m} / \mathrm{z} 348.3[\mathrm{M}+\mathrm{Na}]^{+}$. This reaction gave only a $43 \%$ yield of compound 16, as well as the two previous side products, the formamide derivative 15 in very low yield (20\%) and the amine 1 in $20 \%$ yield.

Another oxadiazinopyranoquinolinone derivative 19 was synthesized by the coupling of bromoacetonitrile (methylene active compound) with diazonium chloride salt 17, in boiling pyridine. Firstly, The non-isolable intermediate compound $\mathbf{1 8}$ is formed by the coupling of diazonium salt $\mathbf{1 7}$ with quaternary salt which produced from the reaction of pyridine and bromoacetonitrile 29 and then underwent intramolecular cyclization to furnish the desired tetracyclic system 19 (Scheme 4). 


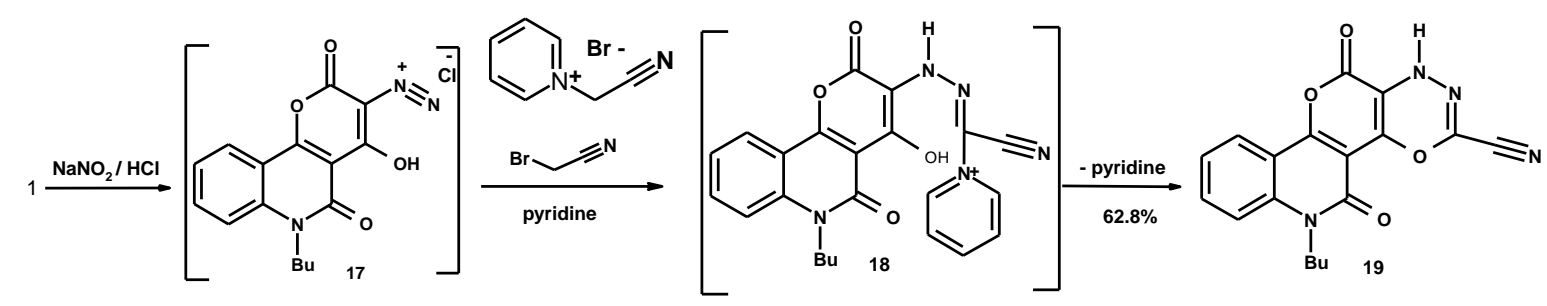

\section{Scheme 4.}

The IR spectrum of compound 19 displayed a new stretching vibration band at $2211 \mathrm{~cm}^{-1}$ due to $C \equiv N$ group. The ${ }^{1} \mathrm{H}$ NMR spectrum of product 19 was characterized by the existence of deuterium exchangeable singlet signal attributed to $\mathrm{NH}$ proton of oxadiazine ring at $11.22 \mathrm{ppm}$. The ${ }^{13} \mathrm{C}-\mathrm{NMR}$ of compound 19 had fourteen signals in the region 99-169 ppm belonging to the aromatic carbon atoms and the cyano group. The mass spectrum of the compound 19 represented the molecular ion peak as the base beak at $m / z 350$ (100\%), which agree well with the proposed formula weight and confirm the suggested structures. ESI-MS spectrum of compound 19 showed a $[\mathrm{M}+\mathrm{H}]^{+}$ion at $m / z 351.3$ and a $[2 \mathrm{M}+\mathrm{Na}]^{+}$ion at $m / z$ 723.3.

\section{Experimental Section}

General. TLC analysis of the reaction mixtures was performed using Fluka analytical silica gel 60 F254 nm TLC plates. For column chromatography, Fluka analytical silica gel 60 0.063-0.2 mm (70-230 mesh ASTM) was used for the separation. Melting points were recorded on Sanyo Gallenkamp MPD 350-BM 3.5 Melting Point apparatus. A Thermo Nicolet Nexus $470 \mathrm{Ft}-\mathrm{IR}$ spectrophotometer was used for IR analyses. ${ }^{1} \mathrm{H}-\mathrm{NMR}(400 \mathrm{MHz})$ and ${ }^{13} \mathrm{C}-\mathrm{NMR}(101 \mathrm{MHz})$ measurements were performed using Varian-400 MHz spectrometer, and chemical shifts were expressed in $\delta$ (ppm) relative to TMS (in $\mathrm{CDCl}_{3}$ or DMSO- $d_{6}$ as solvent) as the internal standard. An EuroEA 3000 Elemental Analyzer (Italy) was used for elemental analyses. Mass spectra were performed using Finnigan 2000, Thermo Quest GC/MS (Italy). A triple-quadruple tandern mass spectrometer (Micromass W Quattro micro ${ }^{T M}$, Waters Corp., Milford, MA, USA) equipped with electrospray ionization (ESI). X-ray diffraction patterns were carried out by XRD-6100 X-ray diffractometer, with CuK $\alpha(\lambda=1.5406 \AA$ ) radiation in the $2 \theta$ range from $5^{\circ}$ to $90^{\circ}$.Compounds 1 and 12 were prepared according to the reported literature methods. ${ }^{25}$

2-((6-n-Butyl-4-hydroxy-2,5-dioxo-5,6-dihydro-2H-pyrano[3,2-c]quinolin-3-yl)amino) acetonitrile (2). A mixture of compound 1 ( $3 \mathrm{~g}, 10 \mathrm{mmol})$ and dry acetonitrile $(50 \mathrm{~mL})$ containing $\mathrm{NaH}(0.24 \mathrm{~g}, 10 \mathrm{mmol})$ was stirred at R.T for 15 minutes under nitrogen gas. During this time, one molar ratio (1.2 $\mathrm{mL}, 10 \mathrm{mmol})$ of bromoacetonitrile was added drop wise to previous mixture. The reaction mixture was heated at reflux for $24 \mathrm{~h}$ and it was monitored by TLC, using ethyl acetate/hexane 7:3 as the eluent. At the end of the reaction, the reaction mixture was filtered on hot and the filtrate was poured on ice (100 g). The dark brown solid ppt. so obtained was filtered off, washed by water $(3 \times 10 \mathrm{~mL})$, dried and crystallized from glacial AcOH to give compound 2. Yield $1.55 \mathrm{~g}(45 \%)$, brown crystals, $\mathrm{mp} 180-181^{\circ} \mathrm{C}$. IR $\left(\mathrm{KBr}, \mathrm{cm}^{-1}\right)$ : 3428 broad band $(\mathrm{OH}), 3203$

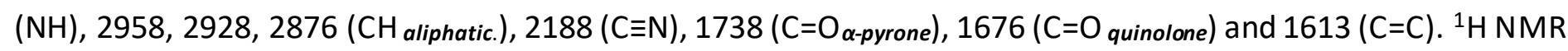
$\left(400 \mathrm{MHz}, \mathrm{DMSO}-d_{6}\right) \delta_{H}: 0.96\left(\mathrm{t}, 3 \mathrm{H}, J=8.0 \mathrm{~Hz}, \mathrm{C4}^{\prime}\right), 1.39-1.48\left(\mathrm{~m}, 2 \mathrm{H}, \mathrm{C} 3^{\prime}\right), 1.63-1.72\left(\mathrm{~m}, 2 \mathrm{H}, \mathrm{C}^{\prime}\right), 4.29(\mathrm{~s}$, 
$\left.2 \mathrm{H}, \mathrm{CH}_{2}-\mathrm{CN}\right), 4.36\left(\mathrm{t}, 2 \mathrm{H}, \mathrm{J} 8.0 \mathrm{~Hz}, \mathrm{Cl}^{\circ}\right), 7.12\left(\mathrm{~s}, 1 \mathrm{H}, \mathrm{N}-\mathrm{H}\right.$, exchangeable in $\left.\mathrm{D}_{2} \mathrm{O}\right), 7.55(\mathrm{t}, 1 \mathrm{H}, J$ 8.0 Hz, C9-H), 7.83$7.94\left(\mathrm{~m}, 2 \mathrm{H}, \mathbf{C 7}-\mathbf{H}\right.$ and C8-H), 8.17 (dd, $1 \mathrm{H}, J$ 8.0,1.6 Hz, C10-H), 14.08 (bs, $1 \mathrm{H}, \mathbf{O H}$, exchangeable in $\left.\mathrm{D}_{2} \mathrm{O}\right) .{ }^{13} \mathrm{C}$

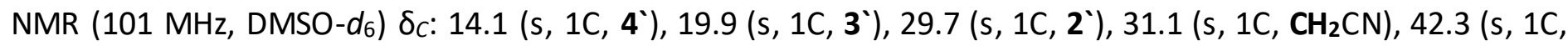
1) 99.9 (s, 1C, 3), 109.9 (s, 1C, 4a), 113.5 (s, 1C, 10a), 116.9 (s, 1 C, C $\equiv$ N ), 117.5 (s, 1C, 7), 124.1 (s, 1C, 10), 124.9 (s, 1C, 9), 134.8 (s, 1C 8), 138.1 (s, 1C, 6a), 156.9 (s, 1C, 10b), 159.5 (s, 1C 2), 163.2 (s, 1C, 4), 163.8 (s, 1C, 5). Mass spectrum, $m / z$ (/rel, \%): $341\left[\mathrm{M}^{+}+2\right](2), 340\left[\mathrm{M}^{+}+1\right](21), 339\left[\mathrm{M}^{+}\right](89), 300$ (37), 299 (58), 245 (17), 244 (100), 189 (5), 188 (38). Anal. Calcd for $\mathrm{C}_{18} \mathrm{H}_{17} \mathrm{~N}_{3} \mathrm{O}_{4}$ (339.35): C, 63.71; H, 5.05; N, 12.38\%. Found: C, 63.78; $\mathrm{H}, 5.15 ; \mathrm{N}, 12.31 \%$.

6-n-Butyl-3-hydroxy-1H-pyrazino[2',3':4,5]pyrano[3,2-c]quinoline-5,12(4H,6H)-dione (7). A mixture of compound 2 (3.3 g, $10 \mathrm{mmol})$, DMF $(50 \mathrm{~mL})$ and $\mathrm{NaH}(0.24 \mathrm{~g}, 10 \mathrm{mmol})$ was heated at reflux for $24 \mathrm{~h}$ and monitored by TLC, using ethyl acetate/hexane 6:4 as the eluent. At the end of the reaction, the reaction mixture was filtered on hot and the filtrate was poured on ice (100 g). The brown solid precipitate so obtained was filtered off, washed by water $(3 \times 10 \mathrm{~mL})$, dried and crystallized from ethanol to give compound 7. Yield $1.02 \mathrm{~g}$ (30.09\%), brown crystals, mp 240-242 ${ }^{\circ} \mathrm{C}$. IR $\left(\mathrm{KBr}, \mathrm{cm}^{-1}\right): 3409$ broad band (OH and $\left.\mathrm{NH}^{\prime} \mathrm{s}\right), 3077$ ( $\left.\mathrm{CH}_{\text {aromatic }}\right), 2959,2918,2842$ ( $\left.\mathrm{CH}_{\text {aliphatic. }}\right), 1714$ ( $\left.\mathrm{C}=\mathrm{O}_{\text {a-pyrone }}\right), 1674$ ( $\left.\mathrm{C}=\mathrm{O}_{\text {quinolone }}\right)$ and 1616 ( $\left.\mathrm{C}=\mathrm{C}_{\text {aromatic }}\right) .{ }^{1} \mathrm{H} \mathrm{NMR}$ $\left(400 \mathrm{MHz}, \mathrm{DMSO}-d_{6}\right) \delta_{H}: 0.90\left(\mathrm{t}, J 8.0 \mathrm{~Hz}, 3 \mathrm{H}, \mathrm{C} 4^{`}\right), 1.31-1.46\left(\mathrm{~m}, 2 \mathrm{H}, \mathrm{C} 3^{\circ}\right), 1.55-1.70\left(\mathrm{~m}, 2 \mathrm{H}, \mathrm{C2}^{\circ}\right), 4.30(\mathrm{t}, J$

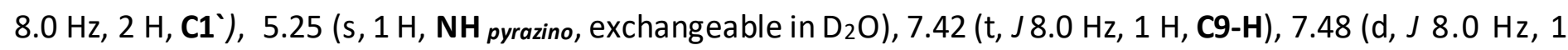

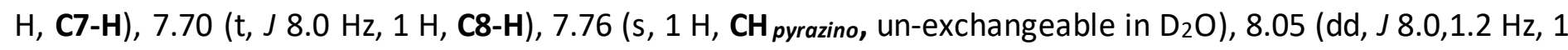

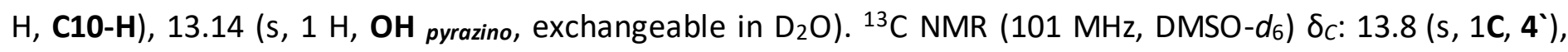
20.3 (s, 1C, 3'), 29.4 (s, 1C, $2^{\circ}$ ), 42.3 (s, 1C, 1') 106.4 (s, 1C, 7), 112.3 (s, 1C, 10a), 114.6 (s, 1C, 9), 119.0 (s, 1C, 10), 122.7 (s, 1C pyrazin), 125.9 (s, 1C, 4a), 128.9 (s, 1C, 8), 129.7 (s, 1C, 3), 133.7 (s, 1C, 4), 135.6 (s, 1C, 6a), 141.3 (s, 1C OH pyrazin), 156.9 (s, 1C, 10b), 157.7 (s, 1C, 2), 161.9 (s, 1C, 5). ESI-MS m/z: $340.4[\mathrm{M}+\mathrm{H}]^{+}, 362.2[\mathrm{M}+\mathrm{Na}]^{+}$, $701.3[2 \mathrm{M}+\mathrm{Na}]^{+}$. Anal. Calcd for $\mathrm{C}_{18} \mathrm{H}_{17} \mathrm{~N}_{3} \mathrm{O}_{4}$ (339.35): C, 63.71; $\mathrm{H}, 5.05 ; \mathrm{N}, 12.38$. Found: $\mathrm{C}, 63.52 ; \mathrm{H}, 5.13 ; \mathrm{N}$, $12.36 \%$.

6-n-Butyl-5,12-dioxo-6H-[1,4]oxazino[2',3:4,5]pyrano[3,2-c]quinoline-2-carbonitrile (8). A mixture of compound 2 ( $3.39 \mathrm{~g}, 10 \mathrm{mmol}$ ) and triethylorthoformate $(8 \mathrm{~mL}, 50 \mathrm{mmol}$ ) was heated for $12 \mathrm{~h}$. The progress of the reaction was monitored by TLC, using ethyl acetate/hexane 6:4 as the eluent. The solid deposited after cooling was filtered off then washed with hot EtOH $(2 \times 10 \mathrm{~mL})$ then crystallized from glacial AcOH to afford compound 8. Yield $1.92 \mathrm{~g}(55 \%)$, orange crystals, $\mathrm{mp} \mathrm{280-282}{ }^{\circ} \mathrm{C}$. IR ( $\left.\mathrm{KBr}, \mathrm{cm}^{-1}\right)$ : $3356(\mathrm{NH}), 2954,2930,2864$ ( $\left.\mathrm{CH}_{\text {aliphatic }}\right), 2197(\mathrm{C} \equiv \mathrm{N}), 1710$ ( $\left.\mathrm{C}=\mathrm{O}_{\text {a-pyrone }}\right), 1677\left(\mathrm{C}=\mathrm{O}_{\text {quinolone }}\right)$ and 1615 ( $\left.\mathrm{C}=\mathrm{C}_{\text {aromatic }}\right) .{ }^{1} \mathrm{H} \mathrm{NMR}(400 \mathrm{MHz}, \mathrm{DMSO}-$

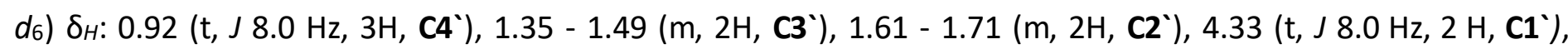
7.48 (t, J $8.0 \mathrm{~Hz}, 1 \mathrm{H}, \mathrm{C} 9-\mathrm{H}), 7.72(\mathrm{~d}, J 8.0 \mathrm{~Hz}, 1 \mathrm{H}, \mathrm{C7}-\mathrm{H}), 7.83$ (t, J $8.0 \mathrm{~Hz}, 1 \mathrm{H}, \mathrm{C} 8-\mathrm{H}), 8.26$ (dd, J 8.0,1.2 Hz, $1 \mathrm{H}$,

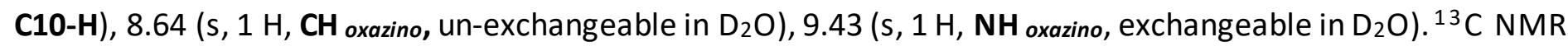

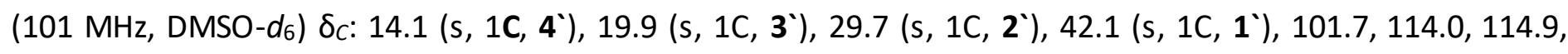
$116.4,124.4,124.9,132.2,134.9,136.1,144.6,151.5,159.0,162.8,163.5,193.9 . \mathrm{ESI}-\mathrm{MS} \mathrm{m} / \mathrm{z}: 350.3[\mathrm{M}+\mathrm{H}]^{+}$, $372.1[\mathrm{M}+\mathrm{Na}]^{+}, 721.1[2 \mathrm{M}+\mathrm{Na}]^{+}$. Anal. Calcd for $\mathrm{C}_{19} \mathrm{H}_{15} \mathrm{~N}_{3} \mathrm{O}_{4}$ (349.35): C, 65.32; H, 4.33; N, 12.03. Found: C, $65.52 ; \mathrm{H}, 4.37 ; \mathrm{N}, 12.11 \%$.

2,2'-((6-n-Butyl-4-hydroxy-2,5-dioxo-5,6-dihydro-2H-pyrano[3,2-c]quinolin-3-yl)azanediyl)diacetonitrile (10). A mixture of compound 1 ( $3 \mathrm{~g}, 10 \mathrm{mmol})$ and dry acetonitrile $(50 \mathrm{~mL})$ containing $\mathrm{NaH}(0.24 \mathrm{~g}, 10 \mathrm{mmol})$ was stirred at R.T for 30 minutes under nitrogen gas. During this time, two molar ratios $(2.5 \mathrm{~mL}, 20 \mathrm{mmol})$ of bromoacetonitrile was added drop wise to previous mixture. The reaction mixture was heated at reflux for 24 $\mathrm{h}$ and it was monitored by TLC, a mixture of ethyl acetate and $\mathrm{n}$-hexane was used as the mobile phase in ratio $(6: 4)$. At the end of the reaction time, the reaction mixture was filtered on hot and the filtrate was poured on 
ice (100 g). The dark brown solid precipitate so obtained was filtered off, washed by water ( $3 \times 10 \mathrm{~mL})$, dried and crystallized from glacial $\mathrm{AcOH}$ to give compound 10. Yield $1.70 \mathrm{~g}(45 \%)$, brown crystals, $\mathrm{mp} 174-176{ }^{\circ} \mathrm{C}$. IR $\left(\mathrm{KBr}, \mathrm{cm}^{-1}\right)$ : 3347 broad band $(\mathrm{OH}), 2959,2926,2850(\mathrm{CH}$ aliphatic.), 2202 very stretching band attributed to two

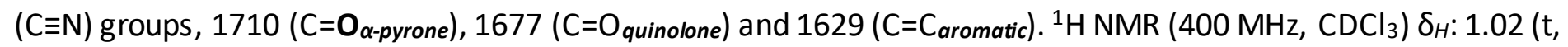

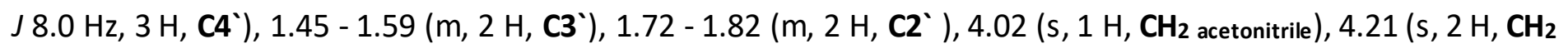
acetonitrile), $4.36\left(\mathrm{t}, J 8.0 \mathrm{~Hz}, 2 \mathrm{H}, \mathrm{C1}^{\prime}\right), 7.48(\mathrm{t}, J 8.0 \mathrm{~Hz}, 1 \mathrm{H}, \mathrm{C} 9-\mathrm{H}), 7.53(\mathrm{~d}, J 8.0 \mathrm{~Hz}, 1 \mathrm{H}, \mathrm{C} 7-\mathrm{H}), 7.80$ (t, J $8.0 \mathrm{~Hz}, 1$ $\mathrm{H}, \mathrm{C} 8-\mathrm{H}), 8.32$ (dd, J 8.0,1.6 Hz, $1 \mathrm{H}, \mathrm{C} 10-\mathrm{H}) .{ }^{13} \mathrm{C}$ NMR (101 MHz, DMSO-d6) $\delta c: 14.1$ (s, $\left.1 \mathrm{C} 4^{\prime}\right), 19.9$ (s, $\left.1 \mathrm{C} 3^{\prime}\right)$, 29.7 (s, 1 C 2'), 41.9 (s, 1 C- CH$_{2}$ acetonitrile), 42.1 (s, 1 C- CH$_{2}$ acetonitrile), 42.3 (s, 1 C 1'), 100.9 (s, 1 C 3), 113.1 (s, 1 C 4a), 113.5 (s, 1 C 10a), 113.9 (s, 1 C 7), 114.5 (s, 1 C, C $\equiv N$ ), 116.1 (s, 1 C, C $\equiv \mathbf{N}$ ), 124.1 (s, 1 C10), 128.9 (s, 1 C 9), 132.3 (s, 1 C 8) 136.1 (s, 1 C 6a), 149.0 (s, 1 C 10b), 159.4 (s, 1 C 2), 162.8 (s, 1 C 4), 163.0 (s, 1 C 5). Mass spectrum, $\mathrm{m} / z$ (Irel, \%): $379\left[\mathrm{M}^{+}+1\right]$ (9), $378\left[\mathrm{M}^{+}\right](41), 339(22), 338\left[\mathrm{M}^{+}-\mathrm{CH}_{2} \mathrm{CN}\right](76), 312(22), 311(100), 285$ (20), 255 (38), 244 (99). Anal. Calcd for $\mathrm{C}_{20} \mathrm{H}_{18} \mathrm{~N}_{4} \mathrm{O}_{4}$ (378.39): C, 63.49; H, 4.79; N, 14.81. Found: $\mathrm{C}, 63.42 ; \mathrm{H}$, 4.82; N, 14.74\%.

\section{2-(6-n-Butyl-3-hydroxy-5,12-dioxo-4,5,6,12-tetrahydro-1Hpyrazino[2',3' :4,5]pyrano[3,2-c]quinolin-1-yl)} acetonitrile (11). A mixture of compound 10 (3.7 g, $10 \mathrm{mmol})$ and DMF (50 mL) with NaH (0.24 g, $10 \mathrm{mmol})$ was added carefully. The reaction mixture was heated at reflux for $24 \mathrm{~h}$ and it was monitored by TLC, a mixture of ethyl acetate and $n$-hexane was used as the mobile phase in ratio (7:3). At the end of the reaction time, the reaction mixture was filtered on hot and the filtrate was poured on ice (100 g). The brown solid precipitate so obtained was filtered, washed several times by water, dried and crystallized from ethanol to give compound 11. Yield $1.2 \mathrm{~g}(30.9 \%)$, brown crystals, $\mathrm{mp} 240-241{ }^{\circ} \mathrm{C} . \mathrm{IR}\left(\mathrm{KBr}, \mathrm{cm}^{-1}\right): 3408$ broad band $(\mathrm{OH}$ and $\mathrm{NH}), 2955,2925,2866$ ( $\mathrm{CH}$ aliphatic.), 2210 ( $\mathrm{C}=\mathrm{N}), 1712$ ( $\left.\mathrm{C}=\mathrm{O}_{\alpha-p y r o n e}\right), 1682$ ( $\mathrm{C}=\mathrm{O}$ quinolone $)$ and 1636 (C=Caromatic). ${ }^{1} \mathrm{H}$ NMR $\left.\left(400 \mathrm{MHz}, \mathrm{CDCl}_{3}\right), \delta_{H}: 1.02(\mathrm{t}, J 8.0 \mathrm{~Hz}, 3 \mathrm{H}, \mathrm{C4})^{\prime}\right), 1.45-1.55\left(\mathrm{~m}, 2 \mathrm{H}, \mathrm{C}^{\prime}\right), 1.71-1.78(\mathrm{~m}$, $\left.2 \mathrm{H}, \mathrm{C2}^{\circ}\right), 4.21\left(\mathrm{~s}, 2 \mathrm{H}, \mathrm{CH}_{2}\right.$ acetonitrile), $4.36\left(\mathrm{t}, J 8.0 \mathrm{~Hz}, 2 \mathrm{H}, \mathrm{C1}^{\circ}\right), 7.51(\mathrm{t}, J 8.0 \mathrm{~Hz}, 1 \mathrm{H}, \mathrm{C9}-\mathrm{H}), 7.79(\mathrm{~d}, J 8.0 \mathrm{~Hz}, 1 \mathrm{H}$, C7-H), 7.86 (t, J 8.0 Hz, 1 H, C8- H), 8.30 (dd, J 8.0, 1.2 Hz, 1 H, C10- H), 8.71 (s, 1 H, CH pyrazino), 10.02 (s, 1 H,

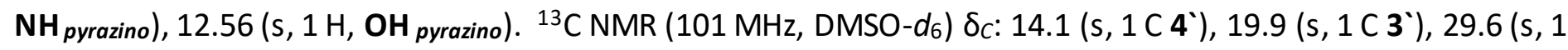
C $2^{\circ}$ ), 40.9 (s, 1 C, CH$_{2}$ acetonitrile), 42.3 (s, 1 C 1'), 113.4 (s, 1 C 4a), 116.9 (s, 1 C- C, 7), 117.5 (s, 1 C C $\equiv \mathbf{N}$ ), 123.2 (s, 1 C 10), 123.6 (s, 1 C 9), 124.1(s, 1 C 10a), 124.9 (s, 1 C CH pyrazino), 133.6 (s, 1 C 8), 134.8 (s, 1 C 3), 138.0 (s, 1 C 4), 138.4 (s, 1 C 6a), 159.5 (s, 1 C-OH pyrazolo), 162.3 (s, 1 C10b), 163.2 (s, 1 C 2), 163.7 (s, 1 C 5). ESI-MS m/z: $379.2[\mathrm{M}+\mathrm{H}]^{+}, 401.2[\mathrm{M}+\mathrm{Na}]^{+}, 779.1[2 \mathrm{M}+\mathrm{Na}]^{1+}$. Anal. Calcd for $\mathrm{C}_{20} \mathrm{H}_{18} \mathrm{~N}_{4} \mathrm{O}_{4}$ (378.39): C, 63.49; $\mathrm{H}, 4.79 ; \mathrm{N}$, 14.81. Found: C, 63.51; $H, 4.74 ; N, 14.87 \%$.

6-n-Butyl-5,12-dioxo-6H-[1,4]oxazino[2:,3:4,5]pyrano[3,2-c]quinoline-3-carbonitrile (13). A mixture of compound 12 (3.55 g, $10 \mathrm{mmol})$ and THF $(50 \mathrm{~mL})$ containing $\mathrm{NaH}(0.24 \mathrm{~g}, 10 \mathrm{mmol})$ was stirred at room temperature for $30 \mathrm{~min}$. Then, one molar ratio $(1.2 \mathrm{~mL}, 10 \mathrm{mmol})$ of bromoacetonitrile was added drop wise to previous mixture. The reaction mixture was heated under reflux for $12 \mathrm{~h}$ and it was monitored by TLC, using ethyl acetate/hexane 7:3 as the eluent. At the end of the reaction, the reaction mixture was filtered on hot and the filtrate was poured on ice (100 g). The orange solid ppt. so obtained was filtered off, washed by water $(3 \times 10 \mathrm{~mL})$, dried and crystallized from glacial AcOH to give compound 13. Yield $2.3 \mathrm{~g}(67 \%)$, orange crystals,

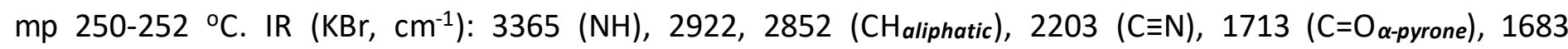
( $\mathrm{C}=\mathrm{O}_{\text {quinolone }}$ ) and 1567 ( $\left.\mathrm{C}=\mathrm{C}_{\text {aromatic }}\right) .{ }^{1} \mathrm{H}$ NMR $\left(400 \mathrm{MHz}, \mathrm{DMSO}-d_{6}\right) \delta_{H}: 0.90\left(\mathrm{t}, J 8.0 \mathrm{~Hz}, 3 \mathrm{H}, \mathrm{C}^{\circ}\right), 1.25-1.45$ (m, 2H, C3') $1.55-1.67\left(\mathrm{~m}, 2 \mathrm{H}, \mathrm{C2}^{`}\right), 4.19\left(\mathrm{t}, J 8.0 \mathrm{~Hz}, 2 \mathrm{H}, \mathrm{C1}^{`}\right), 7.34(\mathrm{t}, J 8.0 \mathrm{~Hz}, 1 \mathrm{H}, \mathrm{C}$ )-H), $7.68(\mathrm{~d}, J 8.0 \mathrm{~Hz}, 1 \mathrm{H}$, C7-H), 7.92 (t, J 8.0 Hz, $1 \mathrm{H}, \mathbf{C} 8-\mathrm{H}), 8.12$ (dd, J 8.0,1.2 Hz, $1 \mathrm{H}, \mathbf{C 1 0}-\mathbf{H}), 8.49$ (s, $1 \mathrm{H}, \mathbf{C H}$ oxazino, un-exchangeable in $\left.\mathrm{D}_{2} \mathrm{O}\right), 11.57$ (s, $1 \mathrm{H}, \mathbf{N H}$ oxazino, exchangeable in $\left.\mathrm{D}_{2} \mathrm{O}\right) .{ }^{13} \mathrm{C}$ NMR (101 MHz, DMSO-d6) $\delta_{c}: 14.1\left(\mathrm{~s}, 1 \mathrm{C}, 4^{\circ}\right), 19.9$ (s, 1C, $\left.3^{\prime}\right), 29.7$ (s, 1C, $\left.2^{`}\right), 42.1$ (s, 1C, $\left.1^{`}\right), 101.7,114.0,115.0,116.3,122.7,124.3,132.10,136.1,138.8,144.4$, 
148.8, 165.7, 158.9, 161.7, 162.8. ESI-MS m/z: $350.1[\mathrm{M}+\mathrm{H}]^{+}, 721.1[2 \mathrm{M}+\mathrm{Na}]^{1+}$. Anal. Calcd for $\mathrm{C}_{19} \mathrm{H}_{15} \mathrm{~N}_{3} \mathrm{O}_{4}$ (349.35): C, 65.32; $H, 4.33 ; N, 12.03$. Found: C, 65.38; $H, 4.36 ; N, 12.10 \%$.

6-n-Butyl-3,6-dihydro-4H-[1,2,4]triazine[6',5':4,5]pyrano[3,2-c]quinoline-5,12(4H)-dione (14a). A mixture of compound $12(3.55 \mathrm{~g}, 10 \mathrm{mmol})$ and hydrazine hydrate $(0.33 \mathrm{~mL}, 10 \mathrm{mmol})$ in $(50 \mathrm{~mL})$ DMF was heated at reflux for $6 \mathrm{~h}$. The progress of the reaction was monitored by TLC, using ethyl acetate/hexane 6:4 as the eluent. The solid deposited after cooling was filtered off and washed with hot EtOH ( $3 \times 10 \mathrm{~mL})$. The targeted compound crystallized from $\mathrm{AcOH}$ to give compound $14 \mathrm{a}$. Yield (1.15 g, 35.5\%), pale yellow crystals, mp 235$237^{\circ} \mathrm{C} . \mathrm{IR}\left(\mathrm{KBr}, \mathrm{cm}^{-1}\right): 3318(\mathrm{NH}), 3200(\mathrm{NH}), 3054$ ( $\left.\mathrm{CH}_{\text {aromatic }}\right), 2952,2922,2872$ ( $\left.\mathrm{CH}_{\text {aliphatic. }}\right), 1712$ (C=O $\alpha$-pyrone), 1666 ( $\left.\mathrm{C}=\mathrm{O}_{\text {quinoline }}\right), 1619(\mathrm{C}=\mathrm{N})$, and $1593\left(\mathrm{C}=\mathrm{C}_{\text {aromatic }}\right) .{ }^{1} \mathrm{H} \mathrm{NMR}\left(400 \mathrm{MHz}, \mathrm{CDCl}_{3}\right) \delta_{H}: 1.02\left(\mathrm{t}, J 8.0 \mathrm{~Hz}, 3 \mathrm{H}, \mathrm{C4}{ }^{`}\right)$,

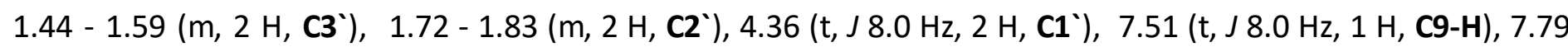
(d, J $8.0 \mathrm{~Hz}, 1 \mathrm{H}, \mathbf{C 7}-\mathrm{H}), 7.86(\mathrm{t}, J 8.0 \mathrm{~Hz}, 1 \mathrm{H}, \mathrm{C} 8-\mathrm{H}), 8.30$ (dd, J 8.0,1.2 Hz, $1 \mathrm{H}, \mathbf{C 1 0}-\mathrm{H}), 8.71\left(\mathrm{~s}, 1 \mathrm{H}, \mathrm{CH}_{\text {triazino }}\right.$ ), $9.10\left(\mathrm{~s}, 1 \mathrm{H}, \mathbf{N H}\right.$, exchangeable in $\left.\mathrm{D}_{2} \mathrm{O}\right), 10.11\left(\mathrm{~s}, 1 \mathrm{H}, \mathbf{N H}\right.$, exchangeable in $\left.\mathrm{D}_{2} \mathrm{O}\right) .{ }^{13} \mathrm{C} \mathrm{NMR}\left(101 \mathrm{MHz}, \mathrm{CDCl}_{3}\right) \delta_{c}$ : 13.8 (s, 1 C 4$^{\prime}$ ) , 20.2 (s, 1C, 3'), 29.5 (s, 1C, 2`), 42.2 (s, 1C, 1'), 106.3, 112.7, 114.7, 122.3, 122.8, 126.0, 130.9,

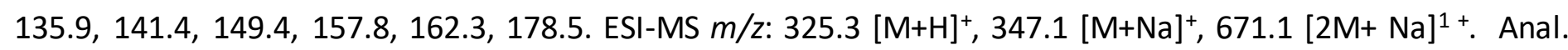
Calcd for $\mathrm{C}_{17} \mathrm{H}_{16} \mathrm{~N}_{4} \mathrm{O}_{3}$ (324.34): C, 62.95; $\mathrm{H}, 4.97 ; \mathrm{N}, 17.27$. Found: $\mathrm{C}, 62.85 ; \mathrm{H}, 4.83 ; \mathrm{N}, 17.33 \%$.

6-n-Butyl-4-phenyl-3,6-dihydro-4H-[1,2,4]triazine[6',5':4,5]pyrano[3,2-c]quinoline-5,12(4H)-dione (14b). A mixture of compound 12 (3.55 g, $10 \mathrm{mmol}$ ) and phenyl hydrazine (1.08 mL, $10 \mathrm{mmol})$ in (50 mL) DMF was heated at reflux for $6 \mathrm{~h}$. The progress of the reaction was monitored by TLC, using ethyl acetate/hexane 6:4 as the eluent. The solid deposited after cooling was filtered off and washed with hot EtOH $(3 \times 10 \mathrm{~mL})$. The targeted compound crystallized from isopropanol to give compound 14b. Yield (1.6 g, 40\%), yellow crystals,

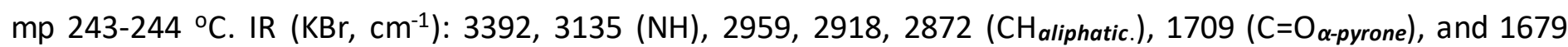
$\left(\mathrm{C}=\mathrm{O}_{\text {quinoline }}\right), 1598(\mathrm{C}=\mathrm{N}), 1582(\mathrm{C}=\mathrm{C}) .{ }^{1} \mathrm{H} \mathrm{NMR}\left(400 \mathrm{MHz}, \mathrm{CDCl}_{3}\right) \delta_{H}: 1.01\left(\mathrm{t}, \mathrm{J} 8.0 \mathrm{~Hz}, 3 \mathrm{H}, \mathrm{C}^{`}\right), 1.44-1.55(\mathrm{~m}, 2$

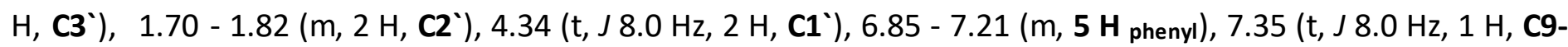
H), 7.51 (d, J $8.0 \mathrm{~Hz}, 1 \mathrm{H}, \mathbf{C 7}-\mathbf{H}), 7.79(\mathrm{t}, J 8.0 \mathrm{~Hz}, 1 \mathrm{H}, \mathbf{C} 8-\mathbf{H}), 8.29$ (dd, J 8.0,1.2 Hz, $1 \mathrm{H}, \mathbf{C 1 0}-\mathrm{H}), 8.38(\mathrm{~s}, 1 \mathrm{H}$, $\mathrm{CH}_{\text {triazino }),} 9.40\left(\mathrm{~s}, 1 \mathrm{H}, \mathbf{N H}\right.$, exchangeable in $\left.\mathrm{D}_{2} \mathrm{O}\right) .{ }^{13} \mathrm{C} \mathrm{NMR}\left(101 \mathrm{MHz}, \mathrm{CDCl}_{3}\right) \delta_{\mathrm{c}}: 13.8\left(\mathrm{~s}, 1 \mathrm{C}^{\prime}\right), 20.1$ (s, $\left.1 \mathrm{C}, 3^{\circ}\right)$, 29.5 (s, 1C, $\left.2^{\circ}\right), 42.6$ (s, 1C, 1'), 101.6 (s, 1C, 4a), 102.4 (s, 1C, 3), 115.0 (s, 1 C 7), 115.5 (s, 1C, 10a ), 119.7 (s, 1C, 10), 122.6 (s, 1C, 9), 124.5 (s, 1C phenyl), 124.8 (s, 1C $\left.C_{\text {phenyl }}\right), 128.3$ (s, $\left.1 C_{\text {phenyl }}\right), 129.3$ (s, $\left.1 C_{\text {phenyl }}\right), 129.8$ (s, $1 \mathrm{C}$

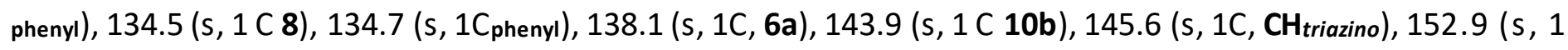
C 4), 162.7 (s, 1C, 2), 163.3 (s, 1C, 5). ESI-MS m/z: $401.4[\mathrm{M}+\mathrm{H}]^{+}, 423.2[\mathrm{M}+\mathrm{Na}]^{+}$. Anal. Calcd for $\mathrm{C}_{23} \mathrm{H}_{20} \mathrm{~N}_{4} \mathrm{O}_{3}$ (400.44): C, 68.99; H, 5.03; N, 13.99. Found: C, 68.85; H, 4.93; N, 13.91\%.

$\mathbf{N}$-(6-n-Butyl-4-hydroxy-2,5-dioxo-5,6-dihydro-2H-pyrano[3,2-c]quinolin-3-yl)formamide (15). This compound was obtained as a side product of the previous reaction and was extracted from the mixture by column chromatography packed with (silica, ethyl acetate/hexane 7:3 as the eluent) as yellow crystals, mp 202-203 ${ }^{\circ} \mathrm{C}$. IR (KBr, cm ${ }^{-1}$ ): $3392(\mathrm{OH}), 3135$ ( $\left.\mathrm{NH}_{\text {amide }}\right), 2959,2918,2872\left(\mathrm{CH}_{\text {alphatic }}\right), 1709$ ( $\left.\mathrm{C}=\mathrm{O}_{\alpha \text {-pyrone }}\right), 1679$ ( $\left.\mathrm{C}=\mathrm{O}_{\text {formyl }}\right), 1656$ ( $\left.C=\mathrm{O}_{\text {quinoline }}\right)$ and 1609 ( $\left.\mathrm{C}=\mathrm{C}_{\text {aromatic }}\right) .{ }^{1} \mathrm{H} \mathrm{NMR}\left(400 \mathrm{MHz}, \mathrm{DMSO}-d_{6}\right) \delta_{H}: 0.90\left(\mathrm{t}, J 8.0 \mathrm{~Hz}, 3 \mathrm{H}, \mathrm{C} 4^{\prime}\right), 1.31-1.44(\mathrm{~m}$, 2H, C 3`), $1.50-1.61\left(\mathrm{~m}, 2 \mathrm{H}, \mathrm{C2}^{`}\right), 4.19\left(\mathrm{t}, J 8.0 \mathrm{~Hz}, 2 \mathrm{H}, \mathrm{C1}^{`}\right), 7.34(\mathrm{t}, J 7.6 \mathrm{~Hz}, 1 \mathrm{H}, \mathrm{C}$ )-H), 7.68 (d, J $8.0 \mathrm{~Hz}, 1 \mathrm{H}$, C7-H), 7.90 (t, J $8.0 \mathrm{~Hz}, 1 \mathrm{H}, \mathbf{C} 8-\mathbf{H}), 8.09$ (d, J $8.0 \mathrm{~Hz}, 1 \mathrm{H}, \mathbf{C 1 0}-\mathbf{H}), 8.49$ (s, $1 \mathrm{H}, \mathbf{N H}$, exchangeable in $\left.\mathrm{D}_{2} \mathrm{O}\right), 10.19$ $\left(\mathrm{s}, 1 \mathrm{H}, \mathrm{CHO}\right.$, partially exchangeable in $\left.\mathrm{D}_{2} \mathrm{O}\right), 11.57\left(1 \mathrm{H}, \mathrm{S}, \mathrm{C}_{4}-\mathrm{OH}\right.$, exchangeable in $\left.\mathrm{D}_{2} \mathrm{O}\right) .{ }^{13} \mathrm{C} \mathrm{NMR}(101 \mathrm{MHz}$,

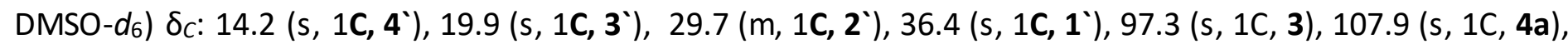
116.6 (s, 1C, 10a), 119.3 (s, 1C, 7), 123.9 (s, 1C, 10), 124.9 (s, 1C, 9), 128.8 (s, 1C, 8), 132.4 (s, 1C, 6a), 134.6 (s, 1 C10b), 149.1 (s, 1C, 2), 158.2 (s, 1C, 4), 163.4 (s, 1C, 5), 177.3 (s, 1 C, -CHO). ESI-MS m/z: 329.3 [M+H], 351.2 $[\mathrm{M}+\mathrm{Na}]^{+}, 657.3[2 \mathrm{M}+\mathrm{H}]^{1+}, 679.3[2 \mathrm{M}+\mathrm{Na}]^{1+}$. Anal. Calcd for $\mathrm{C}_{17} \mathrm{H}_{16} \mathrm{~N}_{2} \mathrm{O}_{5}$ (328.33): C, 62.19; $\mathrm{H}, 4.91 ; \mathrm{N}, 8.53$. Found: $\mathrm{C}, 62.11 ; \mathrm{H}, 4.95 ; \mathrm{N}, 8.43 \%$. 
6-n-Butyl-3,6-dihydro-5H,12H-[1,2,4]oxadiazino[6',5':4,5]pyrano[3,2-c]quinoline-5,12-dione (16). A mixture of compound 12 (3.55 g, $10 \mathrm{mmol}$ ) and hydroxylamine hydrochloride $(0.69 \mathrm{~g}, 10 \mathrm{mmol})$ in (50 mL) DMF was heated at reflux for $8 \mathrm{~h}$. The progress of the reaction was monitored by TLC, a mixture of ethyl acetate and $\mathrm{n}$ hexane was used as the mobile phase in ratio (7:3). The solid deposited after cooling was filtered off and washed with hot EtOH $(3 \times 10 \mathrm{~mL})$. The targeted compound crystallized from AcOH to give compound 16. Yield

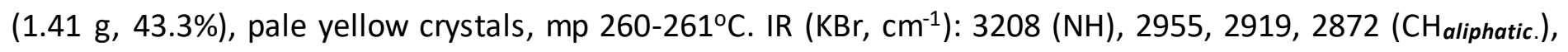
1712 ( $\left.\mathrm{C}=\mathrm{O}_{\alpha \text {-pyrone }}\right), 1666$ ( $\left.\mathrm{C}=\mathrm{O}_{\text {quinoline }}\right), 1619(\mathrm{C}=\mathrm{N})$, and $1593\left(\mathrm{C}=\mathrm{C}_{\text {aromatic }}\right) .{ }^{1} \mathrm{H} \mathrm{NMR}\left(400 \mathrm{MHz}, \mathrm{CDCl}_{3}\right) \delta_{H:} 1.01(\mathrm{t}, \mathrm{J}$ $\left.8.00 \mathrm{~Hz}, 3 \mathrm{H}, \mathrm{C4}^{\circ}\right), 1.49-1.58\left(\mathrm{~m}, 2 \mathrm{H}, \mathrm{C}^{`}\right), 1.68-1.82\left(\mathrm{~m}, 2 \mathrm{H}, \mathrm{C2}^{\circ}\right), 4.35\left(\mathrm{t}, J 8.0 \mathrm{~Hz}, 2 \mathrm{H}, \mathrm{C1}^{\circ}\right), 7.57(\mathrm{t}, J 8.0$ $\mathrm{Hz}, 1 \mathrm{H}, \mathbf{C 9}-\mathrm{H}), 7.76$ (d, J $8.0 \mathrm{~Hz}, 1 \mathrm{H}, \mathrm{C7}-\mathrm{H}), 7.93$ (t, J $8.0 \mathrm{~Hz}, 1 \mathrm{H}, \mathrm{C} 8-\mathrm{H}), 8.33$ (dd, J 8.0,1.2 Hz, $1 \mathrm{H}, \mathrm{C} 10-\mathrm{H}), 9.41$ (s, $1 \mathrm{H}, \mathrm{CH}_{\text {oxadiazine) }}, 12.36\left(\mathrm{~s}, 1 \mathrm{H}, \mathbf{N H}\right.$, exchangeable in $\left.\mathrm{D}_{2} \mathrm{O}\right) .{ }^{13} \mathrm{C} \mathrm{NMR}\left(101 \mathrm{MHz}, \mathrm{CDCl}_{3}\right) \delta_{\mathrm{c}}: 13.8\left(\mathrm{~s}, 1 \mathrm{C}^{\circ}\right), 20.2$ (s, 1C, 3'), 29.5 (s, 1C, 2'), 42.2 (s, 1C, 1'), 106.3, 112.7, 114.7, 122.8, 126.0, 130.9, 135.9, 141.4, 141.8, 149.4, 157.8, 162.3, 178.5. ESI-MS m/z: $326.3[\mathrm{M}+\mathrm{H}]^{+}, 348.3[\mathrm{M}+\mathrm{Na}]^{+}, 673.3[2 \mathrm{M}+\mathrm{Na}]^{1+}$. Anal. Calcd for $\mathrm{C}_{17} \mathrm{H}_{15} \mathrm{~N}_{3} \mathrm{O}_{4}$ (325.33): C, 62.76; $H, 4.65 ; N, 12.92$. Found: C, 62.79; $H, 4.73 ; N, 12.78 \%$.

\section{6-n-Butyl-5,12-dioxo-6,12-dihydro- $1 H, 5 H[1,3,4]$ oxadiazino $\left[6^{\prime}, 5^{\prime}: 4,5\right]$ pyrano[3,2-c]quinoline-3-carbonitrile} (19). Compound 1 ( $3 \mathrm{~g}, 10 \mathrm{mmol})$ was dissolved in conc. $\mathrm{HCl}(50 \mathrm{~mL}, 1 \mathrm{M})$ and the solution was cooled in an ice bath to $0{ }^{\circ} \mathrm{C}$ and a solution of $(0.69 \mathrm{~g}, 10 \mathrm{mmol}) \mathrm{NaNO}_{2} ; 4.00 \mathrm{~mL} \mathrm{HCl}$ was added in $0.5 \mathrm{~mL}$ portions for $1 \mathrm{~h}$. The temperature of the mixture should not exceed $0{ }^{\circ} \mathrm{C}$. Diazonium salt solution prepared above was added drop wise to a mixture of bromoacetonitrile $(1.1 \mathrm{~mL}, 10 \mathrm{mmol})$ with $50 \mathrm{~mL}$ of pyridine. The solution was cooled in an ice bath to $0^{\circ} \mathrm{C}$. After completion of addition, the reaction mixture stirred for $4 \mathrm{~h}$ maintaining the temperature $0-5^{\circ} \mathrm{C}$. Then, the previous mixture was heated at reflux for $12 \mathrm{~h}$. The solid deposited after cooling was filtered off, dried and crystallized from DMF to give compound 19. Yield (2.2 g, 62.85\%), yellow crystals,

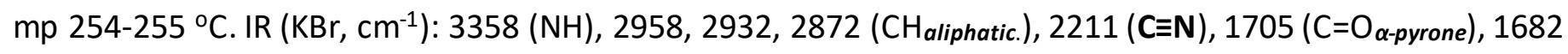
( $\mathrm{C}=\mathrm{O}_{\text {quinolone }}$ ) and $1613(\mathrm{C}=\mathrm{N})$ and $1570\left(\mathrm{C}=\mathrm{C}_{\text {aromatic }}\right) .{ }^{1} \mathrm{H} \mathrm{NMR}\left(400 \mathrm{MHz}, \mathrm{CDCl}_{3}\right) \delta_{H}: 0.99\left(\mathrm{t}, J 8.0 \mathrm{~Hz}, 3 \mathrm{H}, \mathrm{C4}^{\top}\right)$,

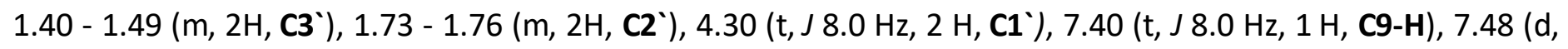
J $8.0 \mathrm{~Hz}, 1 \mathrm{H}, \mathbf{C 7}-\mathrm{H}), 7.75$ (t, J $12.0 \mathrm{~Hz}, 1 \mathrm{H}, \mathbf{C} 8-\mathrm{H}), 8.24$ (dd, J 8.0,1.2 Hz, $1 \mathrm{H}, \mathbf{C 1 0}-\mathbf{H}), 11.22\left(\mathrm{~s}, 1 \mathrm{H}, \mathbf{N H}_{\text {oxadiazine, }}\right.$

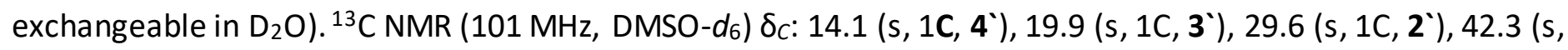
1C, $\left.1^{\circ}\right)$, 99.9, 102.8, 109.9, 113.4, 117.6, 123.2, 124.1, 124.9, 134.8, 148.9, 156.8, 159.5, 163.7, 169.1. ESI-MS $\mathrm{m} / \mathrm{z}: 351.3[\mathrm{M}+\mathrm{H}]^{+}, 373.3[\mathrm{M}+\mathrm{Na}]^{+}, 701.1[2 \mathrm{M}+\mathrm{H}]^{1+}, 723.3[2 \mathrm{M}+\mathrm{Na}]^{1+}$. Anal. Calcd for $\mathrm{C}_{18} \mathrm{H}_{14} \mathrm{~N}_{4} \mathrm{O}_{4}(350.34): \mathrm{C}$, $61.71 ; H, 4.03 ; N, 15.99$. Found: C, 61.79; $H, 4.12 ; N, 15.91 \%$.

\section{References}

1. Akhtar, M. J.; Yar, M. S.; Khan, A. A.; Ali, Z.; Haider, M. R. Mini Rev. Med. Chem. 2017, 17, 1602. https://doi.org/10.2174/1389557516666161031121639

2. Lee, H. Y.; Chang, C. Y.; Su, C. J.; Huang, H. L.; Mehndiratta, S.; Chao, Y. H.; Hsu, C. M.; Kumar, S.; Sung, T. Y.; Huang, Y. Z.; Li, Y. H.; Yang, C. R.; Liou, J. P. Eur. J. Med. Chem. 2016, 122, 92.

https://doi.org/10.1016/i.ejmech.2016.06.023

3. Arafa, R. K; Hegazy, G. H.; Piazza, G. A.; Abadi, A. H. Eur. J. Med. Chem. 2013, 63826. https://doi.org/10.1016/i.ejmech.2013

4. Afzal, O.; Kumar, S.; Haider, M. R.; Ali, M. R.; Kumar, R.; Jaggi, M.; Bawa, S. Eur. J. Med. Chem. 2015, 97, 871. 
5. Magedov, I. V.; Manpadi, M.; Ogasawara, M. A.; Dhawan, A. S.; Rogelj, S.; Van Slambrouck, S. J. Med. Chem. 2008, 51, 2561.

https://doi.org/10.1021/jm701499n

6. Hassanin, H. M.; Serya, R. A. T.; Abd Elmoneam, W. R.; Mostafa, M. A. R Soc Open Sci. 2018, 5, 172407. https://doi.org/10.1098/rsos.172407

7. Upadhyay, K. D.; Dodia, N. M.; Khunt, R. C.; Chaniara, R. S.; Shah, A. K. ACS Med Chem Lett. 2018, 9, 283. https://doi.org/10.1021/acsmedchemlett.7b00545

8. Hassanin, H. M.; Abd Elmoneam, W. R.; Mostafa, M. A. Med Chem Res. 2018, 28, 28. https://doi.org/10.1007/s00044-018-2259-9

9. Ramesh, E.; Manian, R. S.; Raghunathan, R.; Sainath, S.; Raghunathan, M. Bioorg Med Chem. 2009, 17, 660. https://doi.org/10.1016/i.bmc.2008.11.058

10. Anniyappan, M.; Muralidhran, D.; Perumal, P. T. Tetrahedron Lett. 2003, 44, 3653. https://doi.org/10.1016/S0040-4039(03)00707-X

11. El-Agrody, A. M.; Abd-Rabboh, H. S. M.; Al-Ghamd, A. M. Med Chem Res. 2012, 22, 1339. https://doi.org/10.1007/s00044-012-0142-7

12. Yamaguchi, T. Chem. Pharm. Bull. 2007, 55, 532. https://doi.org/10.1248/cpb.55.53212

13. Doležal, M. Chem. Listy 2006, 100, 959.

14. Sawant, R.L; Mhaske, M.S. ; Wadekar, J.B. Internat. J Pharm Sci. 2012, 4, 320.

15. Bhat, A. R.; Pawar, P. D. Indian drugs 2008, 45, 962.

16. Rambabu, N.; Viral, B. M.; Kirti, J. G. Der Pharma Chemica 2012, 4, 511.

17. Patel, K. H.; Mehta, A. G. Der Chemica Sinica 2012, 3, 1410.

18. Ke, S.; Cao, X.; Liang, Y.; Wang, K.; Yang, Z. Mini Rev. Med. Chem. 2011, 11, 642. https://doi.org/10.2174/138955711796268769

19. Ford, K. A.; Casida, J. E.; Chandran, D.; Gulevich, A. G.; Okrent, R. A.; Durkin, K. A.; Sarpong, R.; Bunnelle, E. M.; Wildermuth, M. C. Proc. Natl. Acad. Sci. 2010, 107, 17527.

https://doi.org/10.1073/pnas.1013020107

20. Sławinski, J.; Gdaniec, M. Eur. J. Med. Chem. 2005, 40, 377. [CrossRef] [PubMed] https://doi.org/10.1016/i.ejmech.2004.11.014

21. Saad, H. A.; Moustafa, A. H. Molecules 2011, 16, 5582. [CrossRef] [PubMed] https://doi.org/10.3390/molecules16075682

22. Sztanke, K.; Pasternak, K.; Rzymowska, J.; Sztanke, M.; Kandefer-Szersze ' n, M. Eur. J. Med. Chem. 2008, 43, 1085. [CrossRef] [PubMed] https://doi.org/10.1016/j.ejmech.2007.07.009

23. Sztanke, M.; Rzymowska, J.; Sztanke, K. Bioorg. Med. Chem. 2013, 21, 7465. [CrossRef] [PubMed] https://doi.org/10.1016/j.bmc.2013.09.042

24. Krauth, F.; Dahse, H. M.; Rüttinger, H. H.; Frohberg, P. Bioorg. Med. Chem. 2010, 18, 1816. [CrossRef] [PubMed] https://doi.org/10.1016/j.bmc.2010.01.053

25. Hassanin, H. M.; Abdou, I. M.; Saeed, A. M. Arkivoc 2017, (v), 172. https://doi.org/10.24820/ark.5550190.p010.196

26. Hao, X.; Xu, Z.; Lu, H.; Dai, X.; Yang, T.; Lin, X.; Ren, F. Org. Lett. 2015, 17, 3382. https://doi.org/10.1021/acs.orglett.5b01628 
27. Junga, K.-Y.; Fletcher, S. Med. Chem. Commun. 2012, 3, 1160. https://doi.org/10.1039/c2md20123b

28. Hassanin, H. M.; Hassan, M. M. J. Braz. Chem. Soc. 2018, 29, 792. http://dx.doi.org/10.21577/0103-5053.20170202

29. Allgäuer, D. S.; Mayr, H. Eur. J. Org. Chem. 2013, 2013, 6379. http://dx.doi.org/10.1002/ejoc.201300784 